\title{
ANNOUNCEMENT \\ Ninth Annual Conference on Language Development \\ Call for Papers
}

The Boston University School of Education invites papers for the 9th Annual Conference on Language Development, to be held on October 12, 13, and 14, 1984. Papers on the topics of first and second language acquisition, bilingualism, language disorders, reading, writing, testing and evaluation, sign language, neurolinguistics, sociolinguistics, and language acquisition in disordered populations will be considered for presentation at the conference. The deadline for submission of abstracts is June 1, 1984. This year's keynote speaker is Elinor Ochs from the University of Southern California.

For more information write: Language Development Conference, School of Education, Boston University, Boston, MA 02215.

\section{ANNOUNCEMENT \\ International Conference on Occupational Ergonomics Toronto, Canada, May 7-9, 1984}

The International Conference on Occupational Ergonomics will be held at the Toronto Hilton Harbour Castle in Toronto, Canada, May 7-9, 1984. This is the first international ergonomics meeting that will deal exclusively with ergonomics problems in industry. This conference is aimed at research workers and practicing professionals as well as occupational users of ergonomics. It will bring together people from universities, research institutes, industry, the public sector, and trade unions to share information and explore how ergonomics principles can be used effectively to optimize human performance and well-being in the workplace and to reduce occupational injury and illness.

The technical program has been structured around four types of presentations: introductory workshops (2), advanced workshops (10), reviews (30), and research papers and case studies (130). All plenary sessions and reviews will have simultaneous translation in English or French. Reviews and papers will be published in the conference Proceedings in the language of the author.

To obtain an advance program or for further information, please write to: Y. Ian Noy, Organizing Chairman Toronto '84, P.O. Box 1085, Station B, Rexdale, Ontario, Canada M9V 2 B3. 